\title{
Multiplex PCR for the detection of Piscirickettsia salmonis, Vibrio anguillarum, Aeromonas salmonicida and Streptococcus phocae in Chilean marine farms
}

\author{
D. Tapia-Cammas ${ }^{1}$, A. Yañez $^{2}$, G. Arancibia ${ }^{1}$, A. E. Toranzo ${ }^{3}$, R. Avendaño-Herrera ${ }^{1, *}$ \\ ${ }^{1}$ Laboratorio de Patología de Organismos Acuáticos y Biotecnología Acuícola, Facultad de Ciencias Biológicas, \\ Universidad Andrés Bello, Viña del Mar, Chile \\ ${ }^{2}$ Laboratorio de Enzimología, Instituto de Bioquímica, Facultad de Ciencias, Universidad Austral de Chile, Campus Isla Teja, \\ Casilla 567, Valdivia, Chile \\ ${ }^{3}$ Departamento de Microbiología y Parasitología, CIBUS, Facultad de Biología e Instituto de Acuicultura, \\ Universidad de Santiago de Compostela 15782, Spain
}

\begin{abstract}
A multiplex (m-)PCR-based protocol was designed for the simultaneous detection of the main marine bacterial pathogens in Chilean salmon farms: Streptococcus phocae, Aeromonas salmonicida, Vibrio anguillarum and Piscirickettsia salmonis. Each of the 4 oligonucleotide primer pairs exclusively amplified the target gene of the specific bacterial pathogen. The detection limit of

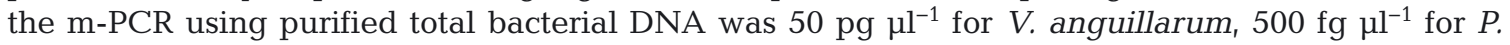
salmonis, and $5 \mathrm{pg}^{-1} \mathrm{l}^{-1}$ for $S$. phocae and A. salmonicida. This corresponded to average limits in the m-PCR sensitivity of $3.69 \times 10^{5} \mathrm{CFU} \mathrm{ml}^{-1}$ of $V$. anguillarum, $1.26 \times 10^{4} \mathrm{CFU} \mathrm{ml}^{-1}$ of $S$. phocae, and $5.33 \times 10^{4} \mathrm{CFU} \mathrm{ml}{ }^{-1}$ of $A$. salmonicida, while the detection limits for the spiked fish tissues, regardless of the sample (spleen, kidney, liver or muscle) were $2.64 \pm 0.54 \times 10^{7} \mathrm{CFU} \mathrm{g}^{-1}$ for $V$. anguillarum,

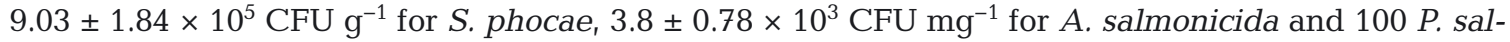
monis cells. However, high amounts of DNA from 3 bacterial species had a reduction of $\sim 1$ log-unit on the amplification sensitivity of $S$. phocae or A. salmonicida when these were present in lower concentration in the multiplex reaction. The assay described in this study is a rapid, sensitive and efficient tool to detect the presence of $S$. phocae, A. salmonicida, V. anguillarum and P. salmonis simultaneously from pure cultures and tissues from clinically diseased fish. Therefore, it may be a useful alternative to culture-based methods for the diagnosis of infections in fish obtained from Chilean salmon farms.
\end{abstract}

KEY WORDS: Multiplex PCR · Fish pathogens · Atlantic salmon · Analytic sensitivity test · Specificity test

Resale or republication not permitted without written consent of the publisher

\section{INTRODUCTION}

The intensive exploitation of salmonids is an activity of high economic importance in Chile, this country being second largest producer of Atlantic salmon Salmo salar in the world (Parada 2010). The production mainly takes place in the south of Chile and is dominated by the marine culture of Atlantic salmon with an estimated production of $\sim 400000 \mathrm{t}$ in 2007 (www.salmonchile.cl). However, after the outbreak of infectious salmon anaemia (ISA) in June 2007 (Godoy et al. 2008), the Chilean aquaculture industry had a reduction of $30 \%$ in total production during 2009 compared to 2007.

In spite of the ISA outbreak, Piscirickettsia salmonis, the causative agent of piscirickettsiosis or salmonid rickettsial septicaemia, is considered the principal agent affecting and causing mortalities in the 
marine Chilean farming every year with annual economic losses of US \$100 million http://aqua. merck-animal-health.com/diseases/piscirickettsiosis/ productadditional_127_113333.aspx. Affected fish are dark in colouration, show inappetence, are lethargic and swim near the surface or in edges of the cages. Internally enlarged spleen, discoloured kidney and anaemia, the principal characteristic of the disease, can be observed. In addition, some fish show distinct circular nodules in the liver (see Fryer \& Hedrick 2003 for review).

In the last decade, incidence of other pathogens such as Streptococcus phocae (Romalde et al. 2008), Vibrio anguillarum (Silva-Rubio et al. 2008) and atypical Aeromonas salmonicida has increased in Chilean salmon culture, provoking significant mortalities also in rainbow trout Onchorhynchus mykiss and Pacific salmon Oncorhynchus kisutch (Bravo 2000, Godoy et al. 2010).

Each disease is diagnosed presumptively based on the clinical signs of the affected fish. However, Streptococcus phocae, Aeromonas salmonicida, Vibrio anguillarum and Piscirickettsia salmonis often appear in mixed infections, increasing the possibility of misdiagnosis commonly attributed to P. salmonis perhaps due to the high incidence of the organism in net-cages. In order to prevent and control outbreaks associated with mixed infections by these 4 pathogens, development of an effective diagnostic method is an important step.

The majority of Chilean laboratories employ isolation from fish tissues on agar media followed by identification using biochemical and/or serological techniques. Until the development of an agar culture medium (Mikalsen et al. 2007, Mauel et al. 2008), cell culture in Chinook salmon embryo (CHSE) cells was considered the gold standard to confirm Piscirickettsia salmonis (Lannan \& Fryer 1991), but both culture methods require intensive labour and are technically demanding.

Polymerase chain reaction (PCR) has been used for rapid detection and identification of each of the above microorganisms not only from plate cultures but also in clinical samples from several fish organs (i.e. kidney, gill, heart, spleen and liver) without further isolation (Gustafson et al. 1992, Miyata et al. 1995, Hirono et al. 1996, Mauel et al. 1996, 1999, Marshall et al. 1998, Gonzalez et al. 2003, Alber et al. 2004, Nilsson et al. 2006, Avendaño-Herrera 2008, Beaz-Hidalgo et al. 2008, Hassan et al. 2008).

Nevertheless, it would be a relatively costly and laborious process if single primer sets were used on a large number of samples in individual PCRs (Altinok et al. 2008). An alternative to singleplex PCR would be the use of simultaneous detection of fish pathogenic bacteria using a multiplex PCR (m-PCR) approach. In the present study, an m-PCR assay was developed for the simultaneous detection of Streptococcus phocae, Aeromonas salmonicida, Vibrio anguillarum and Piscirickettsia salmonis for the rapid and cost effective detection of these pathogens in fish from Chilean salmon aquaculture.

\section{MATERIALS AND METHODS}

\section{Bacterial strains and growth conditions}

The bacterial strains used to evaluate the m-PCR method in this study are presented in Table 1. This

Table 1. Strains used in the present study and results using the specific m-PCR detection method. AtS: Atlantic salmon; RbT: rainbow trout; CoS: Pacific salmon; ChS: Chinook salmon; Tb: turbot; ATCC: American Type Culture Collection (Rockville, USA). *Atypical and ${ }^{* *}$ typical strains

\begin{tabular}{|lccc|}
\hline Bacterial strain & Source & $\begin{array}{c}\text { Isolation source } \\
\text { (AtS/RbT/CoS/ChS/Tb) }\end{array}$ & $\begin{array}{c}\text { No. of strains } \\
\text { detected }\end{array}$ \\
\hline Isolated from diseased fish & & & \\
Piscirickettsia salmonis & Laboratory collection & $0 / 3 / 3 / 1 / 0$ & $0 / 3 / 3 / 1 / 0$ \\
Aeromonas salmonicida & Laboratory collection & $8 * / 0 / 0 / 0 / 3^{* *}$ & $8 / 0 / 0 / 0 / 3$ \\
Streptococcus phocae & Laboratory collection & $13 / 0 / 0 / 0 / 0$ & $13 / 0 / 0 / 0 / 0$ \\
Vibrio anguillarum & Laboratory collection & $1 / 0 / 2 / 0 / 3$ & $1 / 0 / 2 / 0 / 3$ \\
Reference strains & & Phoca vitulina & 1 \\
Streptococcus phocae ATCC 51973 & ATCC & Salmo salar \\
Aeromonas salmonicida subsp. salmonicida ATCC 33658 & ATCC & Salmo trutta & 1 \\
Aeromonas salmonicida subsp. achromogenes ATCC 33659 & ATCC & Salmo gairdneri & 1 \\
Vibrio anguillarum ATCC 43307 & ATCC & Oncorhynchus kisutch & 1 \\
Piscirickettsia salmonis ATCC VR-1361 & ATCC & & \\
\hline
\end{tabular}


collection comprises 31 isolates from Atlantic salmon Salmo salar, Pacific salmon Oncorhynchus kisutch, rainbow trout $O$. mykiss and Chinook salmon $O$. tshawytscha in different Chilean salmon farms and 6 isolates from turbot Psetta maxima. The type strain Streptococcus phocae ATCC $51973^{\mathrm{T}}$, and the reference strains Aeromonas salmonicida subsp. salmonicida ATCC 33658, A. salmonicida subsp. achromogenes ATCC 33659, Vibrio anguillarum ATCC 43307 and Piscirickettsia salmonis ATCC VR-1361 (equivalent to LF-89) were used as positive controls and were obtained from the American Type Culture Collection.

In addition, reference strains of other pathogens from fish and mammals also obtained from outbreaks were included to test specificity of the m-PCR (Table 2). The identity of each isolate was confirmed by standard phenotypical and microscopical techniques as reported by MacFaddin (1980) and also in some cases using PCR-based analysis or serological assays.

For all experiments, Aeromonas salmonicida and Vibrio anguillarum strains were routinely grown on tryptone soya agar or broth supplemented with $1 \%$ (w/v) sodium chloride (TSA-1 or TSB-1, respectively) at $20^{\circ} \mathrm{C}$ for 24 to $72 \mathrm{~h}$. Columbia sheep blood agar plates (CBA; AES Laboratory) were used to culture Streptococcus phocae. For Piscirickettsia salmonis, BFCG agar (5\% sheep blood agar plates that had the addition of $3 \%$ fetal bovine serum [FBS], $0.1 \%$ cys-

Table 2. Bacteria from other species included in this study as negative controls in the m-PCR analysis. NBRC: National Institute of Technology and Evaluation (NITE) Biological Resource Center (Osaka, Japan); ATCC: American Type Culture Collection (Rockville, MD, USA); NCIMB: National Collection of Industrial and Marine Bacteria (Aberdeen, UK); CECT: Colección Española de Cultivos Tipos (Universidad de Valencia, Spain). No specific amplification was detected for any strain. Values in parentheses: number of strains assayed

\begin{tabular}{|c|c|c|}
\hline Bacterial strain & Source & $\begin{array}{c}\text { Detection by } \\
\text { m-PCR }\end{array}$ \\
\hline Vibrio spp. (5) isolated from diseased fish & Laboratory collection & - \\
\hline Vibrio ordalii (18) & Laboratory collection & - \\
\hline Vibrio ordalii ATCC 33509 & ATCC & - \\
\hline Vibrio harveyi TW425 & Laboratory collection & - \\
\hline Vibrio splendidus I CPV8.1 & Laboratory collection & - \\
\hline Vibrio splendidus II AZ206 & Laboratory collection & - \\
\hline Vibrio alginolyticus ATCC $17749^{\mathrm{T}}$ & ATCC & - \\
\hline Vibrio pelagius I TW487/02 & Laboratory collection & - \\
\hline Vibrio pelagius II RI 152.1 & Laboratory collection & - \\
\hline Aeromonas hydrophila 1404 & Laboratory collection & - \\
\hline Streptococcus parauberis RA9 & Laboratory collection & - \\
\hline Lactococcus garvieae TW94W & Laboratory collection & - \\
\hline Photobacterium damselae subsp. piscicida ATCC 29690 & ATCC & - \\
\hline Photobacterium damselae subsp. damselae AZ247.1 & Laboratory collection & - \\
\hline Pseudomonas anguilliseptica CECT 899 & CECT & - \\
\hline Tenacibaculum maritimum NCIMB 2158 & NCIMB & - \\
\hline Tenacibaculum maritimum NCIMB2153 & NCIMB & - \\
\hline Tenacibaculum ovolyticum NBRC 15947 & NBRC & - \\
\hline Tenacibaculum ovolyticum NBRC 15992 & NBRC & - \\
\hline Tenacibaculum mesophilum NBRC $16307^{\mathrm{T}}$ & NBRC & - \\
\hline Tenacibaculum mesophilum NBRC 16308 & NBRC & - \\
\hline Tenacibaculum amylolyticum NBRC $16310^{\mathrm{T}}$ & NBRC & - \\
\hline Tenacibaculum lutimaris DMS 16505 & DMS & - \\
\hline Rhodococcus qingshengii 79043-3 & Laboratory collection & - \\
\hline Flavobacterium psychrophilum $49418^{\mathrm{T}}$ & ATCC & - \\
\hline Flavobacterium columnare ATCC $23462^{\mathrm{T}}$ & ATCC & - \\
\hline Yersinia ruckeri CECT 955 & CECT & - \\
\hline Francisella sp. LM-84-F & Laboratory collection & - \\
\hline Chryseobacterium piscicola CECT $7357^{\mathrm{T}}$ & CECT & - \\
\hline Chryseobacterium chaponense Sa $1147-06^{\mathrm{T}}$ & Laboratory collection & - \\
\hline Hafnia alvei 15/1403 & Laboratory collection & - \\
\hline Enterobacter cloacae TW 03/03 & Laboratory collection & - \\
\hline Enterobacter aerogenes RPM799.1 & Laboratory collection & - \\
\hline Escherichia coli FV9180 & Laboratory collection & - \\
\hline
\end{tabular}


teine and $1 \%$ glucose) was used and incubated at $16^{\circ} \mathrm{C}$ for $6 \mathrm{~d}$ (Mauel et al. 2008). Stock cultures were stored at $-80^{\circ} \mathrm{C}$ in Cryo-bille tubes (AES Laboratory).

\section{DNA extraction}

Total DNA was extracted for subsequent analysis using 2 different commercial systems: InstaGene Purification Matrix (Bio-Rad Laboratories) for pure and mixed bacterial cultures and AxyPrep ${ }^{\mathrm{TM}}$ Multisource Genomic DNA Miniprep Kit (Axygen Biosciences) for tissue samples. In all cases, DNA purification was performed according to the manufacturer's instructions. The concentration and quality of each DNA sample was examined spectrophotometrically at $260 \mathrm{~nm}$ on an Epoch ${ }^{\mathrm{TM}}$ Microplate Spectrophotometer. DNA from pure cultures was adjusted with sterile distilled water to a concentration of $50 \pm$ $5 \mathrm{ng} \mathrm{\mu l}^{-1}$. Of each DNA sample extracted, $1 \mu \mathrm{l}$ (10 to $5 \mathrm{ng}$ ) was used directly for m-PCR amplification, and the remaining DNA sample was stored at $-20^{\circ} \mathrm{C}$. All experiments were carried out with DNA obtained in 2 independent extractions for each bacterial strain and isolate.

\section{PCR amplification}

All PCR amplifications were performed using a Mastercycler personal (Eppendorf) and the commercial kit Ready-To-Go ${ }^{\mathrm{TM}}$ PCR beads (GE Healthcare) according to the manufacturer's instructions. This kit included all the reagents needed for the PCR reactions (buffer, nucleotides and Taq DNA polymerase), with the exception of the specific primers and DNA template. The sequences of the $4 \mathrm{PCR}$ primer pairs for $\mathrm{m}-\mathrm{PCR}$ and the expected size of PCR products generated with these primers are shown in Table 3.
The PCR annealing temperatures tested ranged from 50 to $60^{\circ} \mathrm{C}$. Intensity of the amplicons for each target DNA, as well as the absence of nonspecific bands, was considered in selecting m-PCR conditions. Therefore, $55^{\circ} \mathrm{C}$ was used as the annealing temperature for all PCRs. The cycling protocol was 1 cycle of $95^{\circ} \mathrm{C}$ for $3 \mathrm{~min}, 35$ cycles of $95^{\circ} \mathrm{C}$ for $1 \mathrm{~min}, 55^{\circ} \mathrm{C}$ for $1 \mathrm{~min}$ and $72^{\circ} \mathrm{C}$ for $1 \mathrm{~min}$, followed by a final elongation at $72^{\circ} \mathrm{C}$ for $2 \mathrm{~min}$.

\section{Analysis of PCR products}

Aliquots of $10 \mu \mathrm{l}$ of PCR product were separated on a $1.5 \%(\mathrm{w} / \mathrm{v})$ agarose gel for $60 \mathrm{~min}$ at $100 \mathrm{~V}$ in TAE $1 \times$ (0.04 M Tris, 0.0001 M EDTA, pH 8.0) electrophoresis buffer, visualized using $0.06 \mu \mathrm{g} \mathrm{ml}^{-1}$ of ethidium bromide (Bio-Rad) and photographed under UV light. A 100 bp DNA ladder (100-1000 bp; Bioron) and GeneRuler ${ }^{\mathrm{TM}} 100$ bp DNA Ladder Plus (100-3000 bp; Fermentas) were used as molecular mass markers. In all cases, negative controls consisting of the same reaction mixture, but with sterile distilled water instead of template DNA, were included in each batch of PCR reactions. The presence of a single product of the appropriate size, identical to the respective reference strains, was considered as a positive result.

\section{Specificity and sensitivity from pure cultures}

The specificity of the m-PCR was evaluated using the genomic DNA extracted from 37 related bacteria and an additional 55 different fish pathogens or unrelated bacteria from human (Table 2).

For the evaluation of the analytic sensitivity of $\mathrm{m}-\mathrm{PCR}$, the minimum detectable amounts of targeted DNA by m-PCR were detected for Streptococ-

Table 3. Specific primers for m-PCR used in the present study

\begin{tabular}{|c|c|c|c|c|c|}
\hline Bacterial species & $\begin{array}{l}\text { Target } \\
\text { gene }\end{array}$ & Primer & Sequence $\left(5^{\prime}-3^{\prime}\right)$ & $\begin{array}{l}\text { Amplicon } \\
\text { size (bp) }\end{array}$ & Source \\
\hline $\begin{array}{l}\text { Vibrio } \\
\text { anguillarum }\end{array}$ & $\operatorname{rpoN}$ & $\begin{array}{l}\text { rpoN-ang5' } \\
\text { rpoN-ang3' }\end{array}$ & $\begin{array}{l}\text { GTTCATAGCATCAATGAGGAG } \\
\text { GAGCAGACAATATGTTGGATG }\end{array}$ & 519 & Gonzalez et al. (2003) \\
\hline $\begin{array}{l}\text { Piscirickettsia } \\
\text { salmonis }\end{array}$ & 16S-23S RNA & $\begin{array}{l}\text { RTS1 } \\
\text { RTS2 }\end{array}$ & $\begin{array}{l}\text { TGATTTTATTGTTTAGTGAGAATGA } \\
\text { AAATAACCCTAAATTAATCAAGGA }\end{array}$ & 91 & Marshall et al. (1998) \\
\hline $\begin{array}{l}\text { Aeromonas } \\
\text { salmonicida }\end{array}$ & $\operatorname{vap} A$ & $\begin{array}{l}\text { AP-1 } \\
\text { AP-2 }\end{array}$ & $\begin{array}{l}\text { GGCTGATCTCTTCATCCTCACCC } \\
\text { CAGAGTGAAATCTACCAGCGGTGC }\end{array}$ & 421 & Gustafson et al. (1992) \\
\hline $\begin{array}{l}\text { Streptococcus } \\
\text { phocae }\end{array}$ & 16S rRNA & $\begin{array}{c}\text { PX1 } \\
\text { PXVQ2 }\end{array}$ & $\begin{array}{l}\text { GCTAATACCGCATAAGAAGAG } \\
\text { CACCСTGTCACTTCTGCTC }\end{array}$ & 900 & $\begin{array}{l}\text { Hassan et al. (2008) } \\
\text { Avendaño-Herrera (2008) }\end{array}$ \\
\hline
\end{tabular}


cus phocae ATCC $51973^{\mathrm{T}}$, Aeromonas salmonicida subsp. salmonicida ATCC 33658 or A. salmonicida subsp. achromogenes ATCC 33659, Vibrio anguillarum ATCC 43307 and Piscirickettsia salmonis ATCC VR-1361 strains as denoted by Onuk et al. (2010). After DNA extraction, serial dilutions of each DNA were prepared with sterile distilled water at

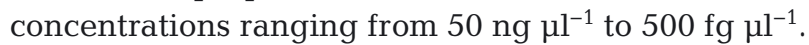
Aliquots of $10 \mu \mathrm{l}$ of each dilution of DNA were mixed with the respective aliquots of the other 3 strains. These DNA mixtures were used as template DNA for the m-PCR experiments, and the detection limit for DNA was determined.

For the evaluation of analytic sensitivity of m-PCR from the cultures, based on bacterial cell numbers, separate bacterial suspensions of the Streptococcus phocae, Aeromonas salmonicida, Vibrio anguillarum and Piscirickettsia salmonis strains were prepared to contain $10^{9}$ cells ml ${ }^{-1}$ (McFarland Scale 4) and were 10 -fold diluted in $0.85 \%$ sterile saline solution from $10^{8}$ to 10 cells ml $^{-1}$. Thus, bacterial mixtures with the different fish pathogens were prepared and used as DNA template for m-PCR sensitivity testing. Chromosomal DNA was extracted as described previously, and CFU ml ${ }^{-1}$ was estimated in all cases by plating onto agar plates. Limits of detection were determined based on presence or absence of PCR products on gels.

\section{Determination of m-PCR sensitivity from spiked fish samples}

M-PCR sensitivity was determined employing DNA extracted from in vitro spiked spleen, kidney, liver and muscle of juvenile healthy Atlantic salmon as described by Avendaño-Herrera et al. (2004). Each fish sample (mean weight: 16.3 to $12.2 \mathrm{mg}$ ) was spiked with $100 \mu \mathrm{l}$ of one of the bacterial dilutions (from $10^{8}$ to $10^{2}$ cells $\mathrm{ml}^{-1}$ ) from pure cultures of 4 bacterial species and homogenized in phosphate buffered saline (PBS, pH 7.4) for $60 \mathrm{~s}$. After incubation for $1 \mathrm{~h}$ at $18^{\circ} \mathrm{C}$, DNA was extracted using AxyPrep ${ }^{\mathrm{TM}}$ Multisource Genomic DNA Miniprep Kit according to the manufacturer's instructions. Noninoculated spiked samples, serving as negative controls, were processed in the same manner but with sterile saline solution instead of bacterial dilutions. For $\mathrm{m}-\mathrm{PCR}, 1 \mu \mathrm{l}$ of the purified DNA was added as template. Again, limits of detection were determined based on presence or absence of PCR products in gels.
The analytic sensitivity of the m-PCR was also determined using spiked kidney tissue from Atlantic salmon with different relative amounts of Streptococcus phocae, Aeromonas salmonicida subsp. salmonicida or subsp. achromogenes, Vibrio anguillarum and Piscirickettsia salmonis. Here, $100 \mu \mathrm{l}$ of suspension from each one of 3 bacterial species containing $\sim 10^{7} \mathrm{CFU} \mathrm{ml}{ }^{-1}$ was mixed with the same amount of a suspension of the fourth pathogen containing $10^{4}$ to $10^{5} \mathrm{CFU} \mathrm{ml}{ }^{-1}$. This low concentration was selected considering the sensitivity obtained from the in vitro spiked tissues described above.

\section{RESULTS AND DISCUSSION}

Rapid diagnosis of outbreak agents is essential for effective control, but current microbiological methods based on culture and biochemical characterization are time-consuming. An m-PCR approach has been successfully applied to detect multiple bacterial pathogens of marine (Kulkarni et al. 2009) and/or freshwater fish (del Cerro et al. 2002, Mata et al. 2004, Altinok et al. 2008, Altinok 2011).

Salmonid rearing in Chile has been seriously threatened by the appearance of a number of diverse bacterial pathogens. In this investigation, an m-PCR method was developed to detect 4 marine pathogens, Streptococcus phocae, Aeromonas salmonicida, Vibrio anguillarum and Piscirickettsia salmonis simultaneously. Firstly, the analytic specificity of the 4 primer sets was determined using the DNA extracted from 37 strains belonging to the 4 targeted species (Table 1), DNA from individual strains being added to reactions. All 4 oligonucleotide primer pairs exclusively amplified the target gene of the specific bacterial pathogen, producing a unique and clear PCR product of the expected length for the corresponding microorganism (Fig. 1). With other strains or isolates used in this study, neither specific nor false-positive bands were detected (Table 2).

The m-PCR condition was optimized for the simultaneous detection of the 4 microorganisms, particularly the annealing temperature, and the best amplification for all primer pairs being obtained at $55^{\circ} \mathrm{C}$. The analytic specificity of the m-PCR assay was confirmed using a DNA mixture prepared from the 4 pathogens that gave amplification products of $900 \mathrm{bp}$ for Streptococcus phocae, 421 bp for Aeromonas salmonicida, $512 \mathrm{bp}$ for Vibrio anguillarum and $91 \mathrm{bp}$ for Piscirickettsia salmonis (Fig. 1). No amplification was observed when DNA from other taxonomically and/or ecologically related bacteria were combined 


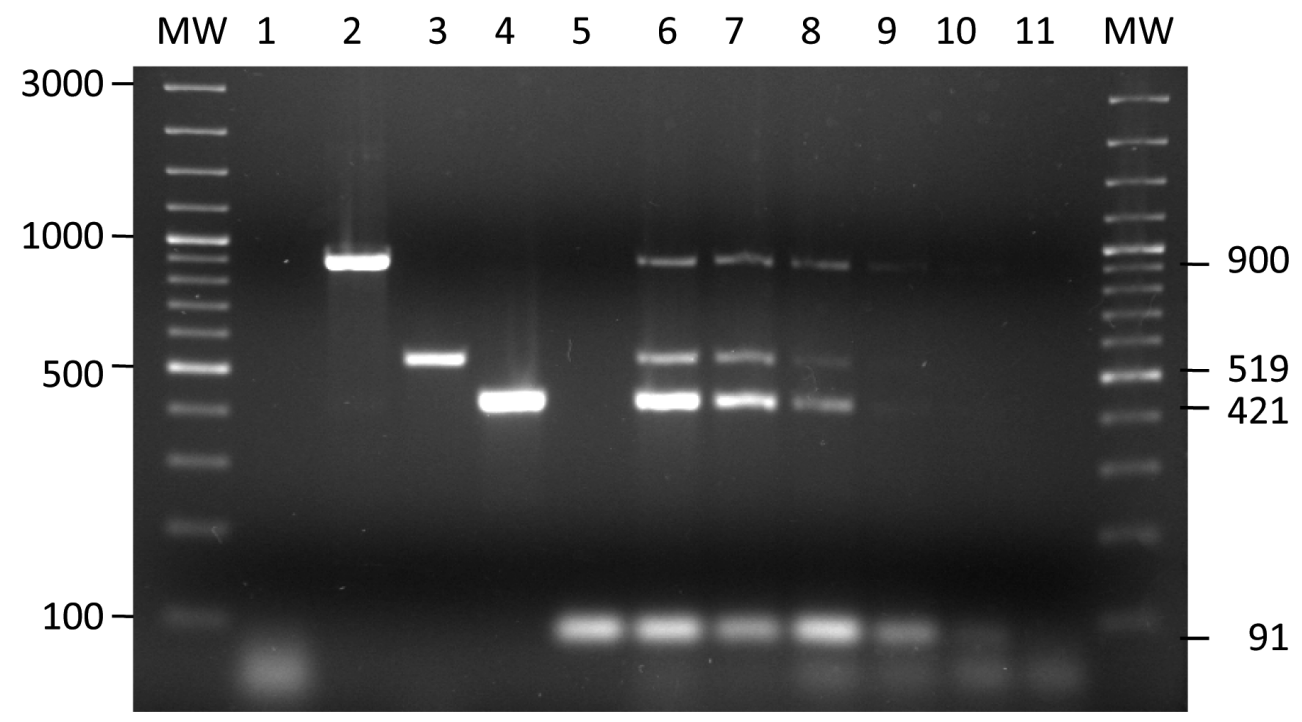

Fig. 1. Aeromonas salmonicida, Streptococcus phocae, Vibrio anguillarum, and Piscirickettsia salmonis. Amplification products from m-PCR assay developed for the simultaneous detection of streptococcosis, typical and atypical furunculosis, vibriosis and piscirickettsiosis. MW: GeneRuler ${ }^{\mathrm{TM}}$ 100bp DNA Ladder Plus (100-3000 bp; Fermentas). Lanes 1 to 5: (1) negative control (no DNA), (2) S. phocae ATCC 51973 ${ }^{\mathrm{T}}$, (3) A. salmonicida subsp. achromogenes ATCC 33659, (4) V. anguillarum ATCC 43307, (5) P. salmonis ATCC VR-1361. Lanes 6 to 11: sensitivity of m-PCR in detecting the 4 fish pathogens from serially diluted (5 ng $\mu^{-1}$ to $50 \mathrm{fg}^{-1} \mathrm{l}^{-1}$ ) chromosomal DNA extracted from reference strains of each fish pathogen. Left $y$-axis: position of molecular size marker (bp); right $y$-axis: size of specific amplified products (bp)

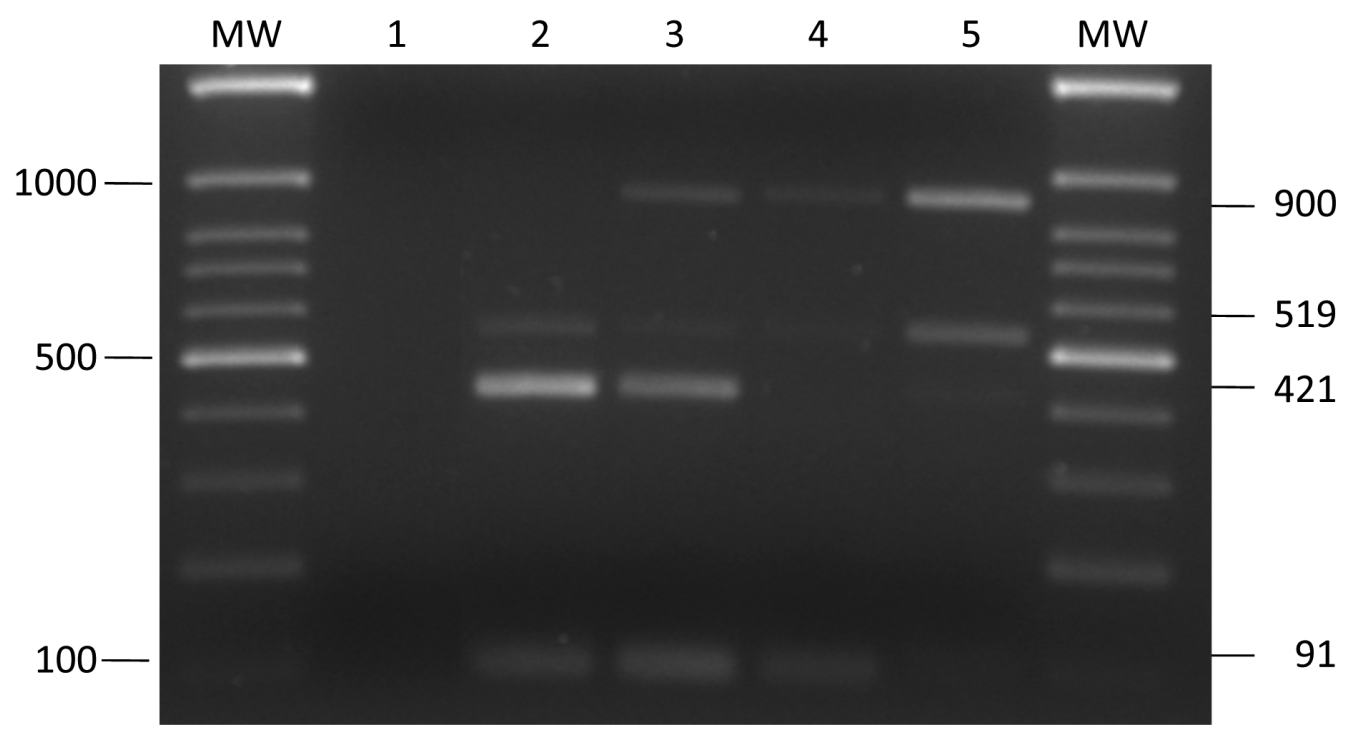

Fig. 2. Aeromonas salmonicida, Streptococcus phocae, Vibrio anguillarum, and Piscirickettsia salmonis. Detection by m-PCR of fish tissue samples containing a high amount of 3 pathogens $\left(10^{7} \mathrm{CFU} \mathrm{ml^{-1 }}\right.$ each bacterium) and low amounts of the fourth pathogen $\left(10^{4}\right.$ to $\left.10^{5} \mathrm{CFU} \mathrm{ml} \mathrm{ml}^{-1}\right)$. CFU were estimated by standard plate counts. MW: Axygen 100bp DNA Ladder (100-3000 bp); Lane 1: negative control (no DNA); Lanes 2 to 5: DNA extracted from tissues spiked with (2) S. phocae ATCC $51973^{\mathrm{T}}$ at $10^{4} \mathrm{CFU} \mathrm{ml}^{-1}$, (3) V. anguillarum ATCC 43307 at $10^{5} \mathrm{CFU} \mathrm{ml}^{-1}$, (4) A. salmonicida subsp. achromogenes ATCC 33659 at $10^{4} \mathrm{CFU} \mathrm{ml}^{-1}$, and (5) P. salmonis ATCC VR-1361 $\left(\sim 150 \mathrm{fg}^{\mathrm{l}} \mathrm{l}^{-1}\right)$

together, with the exception of $V$. splendidus and $V$. pelagius, giving a unique, non-specific (i.e. based on size) PCR amplification product of weak intensity (unpubl. data). This can be explained by the high degree of genetic relatedness of the Vibrio species, which is defined as a group of strains that share $>95 \%$ DNA identity in multilocus sequence analysis (MLSA) (Thompson et al. 2009). 
The analysis of sensitivity and robustness of the mPCR protocol for the 4 species was determined by amplification of pure DNA of each reference strain in duplicate. The range of detection using purified DNA

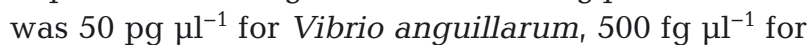

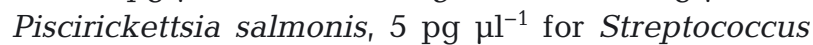
phocae and Aeromonas salmonicida, respectively (Fig. 1). In the case of DNA extracted from bacterial suspensions, the average limits in the m-PCR sensitivity for each species were $1.26 \times 10^{4} \mathrm{CFU} \mathrm{ml}^{-1}$ of $S$. phocae, $3.69 \times 10^{5} \mathrm{CFU} \mathrm{ml}^{-1}$ of $V$. anguillarum and $5.33 \times 10^{4} \mathrm{CFU} \mathrm{m} \mathrm{m}^{-1}$ of $A$. salmonicida, while the detection limits for the spiked fish tissues was the same, regardless of the tissue type, with $9.03 \pm 1.84 \times$ $10^{5} \mathrm{CFU} \mathrm{g}^{-1}$ for $S$. phocae, $2.64 \pm 0.54 \times 10^{7} \mathrm{CFU} \mathrm{g}^{-1}$ for $V$. anguillarum, $3.8 \pm 0.78 \times 10^{3} \mathrm{CFU} \mathrm{g}^{-1}$ for $A$. salmonicida and 100 P. salmonis cells.

Although the Piscirickettsia salmonis strain grew on BFCG agar (Mauel et al. 2008), poorly defined colonies were produced, leading to inaccuracies in estimations of the CFU concentration. In fact, the bacterial count showed that the number of culturable bacteria decreased by $3 \log$-units $\left(10^{5} \mathrm{CFU} \mathrm{ml} \mathrm{m}^{-1}\right)$ from an initial inoculum of $10^{8}$ cells $\mathrm{ml}^{-1}$. This difficulty leads us to express the sensitivity of $P$. salmonis in DNA concentration units or cells only.

Taking into consideration our detection limit, the simultaneous use of the 4 PCR primer pairs in one PCR resulted in a reduction in analytical sensitivity for Aeromonas salmonida and Vibrio anguillarum compared to that previously reported in the literature (Gustafson et al. 1992, Gonzalez et al. 2003). In this context, our m-PCR procedure possesses similar detection limits for Streptococcus phocae and Piscirickettsia salmonis to those previous results obtained by Avendaño-Herrera (2008) and Marshall et al. (1998), respectively. In fact, Avendaño-Herrera (2008) has reported for $S$. phocae detection level on the order of $10^{4} \mathrm{CFU} \mathrm{ml}^{-1}$ in bacterial suspension and $10^{6} \mathrm{CFU} \mathrm{g}^{-1}$ in tissues, while for P. salmonis, Marshall et al. (1998) suggest that the simple PCR assay is capable of revealing the presence of 10 to $100 \mathrm{P}$. salmonis cells. The m-PCR procedure constitutes a powerful tool for accurate identification of different pathogens from plate cultures as well as from fish tissues (del Cerro et al. 2002, Mata et al. 2004, Altinok et al. 2008, Kulkarni et al. 2009, Onuk et al. 2010). However, an important aspect is that this m-PCR is generally thought to be less sensitive than single PCR due to competition for reaction reagents among the assays making up the multiplex technique, especially if the assays are different in their amplification efficiency or one or more of the target organisms are present in high numbers. In our investigation, the use of high amounts of DNA from 3 bacterial species $\left(10^{7} \mathrm{CFU}\right.$ $\mathrm{ml}^{-1}$ of each pathogen) had a significant effect on the amplification sensitivity of the other bacterial species only when $A$. salmonicida or $S$. phocae were present in lower concentrations $\left(10^{4}\right.$ to $\left.10^{5} \mathrm{CFU} \mathrm{ml}^{-1}\right)$ in the multiplex reaction. In fact, the limits of detection of the $S$. phocae decreased by 1 log-unit $\left(10^{6} \mathrm{CFU} \mathrm{g}^{-1}\right)$ when high amounts of amplification of the other 3 target bacterial DNA occurred (Fig. 2). No amplification product was observed when DNA of A. salmonicida at lower DNA concentrations $\left(10^{5} \mathrm{CFU} \mathrm{ml}^{-1}\right)$ was tested in the presence of higher DNA concentrations $\left(10^{7} \mathrm{CFU} \mathrm{ml} \mathrm{m}^{-1}\right)$ of the other target species. We can speculate that a possible cause can be due to the primer length used and the nucleotide content. Our results are in agreement with Altinok (2011) who noted that the high amounts of DNA from one bacterial species had a significant effect on the amplification sensitivity of the other bacterial species when these are present in lower concentration in the multiplex reaction.

Nevertheless the level of sensitivity is probably sufficient to detect each pathogen in acute infections in fish. For the diagnosis of fish diseases caused by slow-growing bacteria such as Aeromonas salmonicida or Streptococcus phocae, PCR-based detection is of particular importance because these bacteria can be easily obscured by Piscirickettsia salmonis and are therefore likely to be underdiagnosed based on cultivation only. Furthermore, m-PCR assay is more rapid and cost-effective than singleplex PCR. In summary, this m-PCR can be an efficient tool to detect the presence of $S$. phocae, A. salmonicida, Vibrio anguillarum and $P$. salmonis simultaneously from pure cultures and tissues obtained from clinically diseased fish with high bacterial concentrations. It could therefore be a useful alternative to culture-based methods for the diagnosis of infections in Chilean salmon farms.

Acknowledgements. Funding for this study was provided in part by Grant FONDECYT 1090054 from the Comisión Nacional de Investigación Científica y Tecnológica-CONICYT (Chile) and also by Grant DI-01-10/R from the Universidad Andres Bello.

\section{LITERATURE CITED}

Alber J, El-Sayed A, Lämmler C, Hassan AA, Vossen A, Siebert U (2004) Determination of species-specific sequences of superoxide dismutase A encoding gene sodA and chaperonin 60 encoding gene cpn60 for identification and phylogenetic analysis of Streptococcus phocae. Vet Microbiol 101:117-122 
Altinok I (2011) Multiplex PCR assay for detection of four major bacterial pathogens causing rainbow trout disease. Dis Aquat Org 93:199-206

Altinok I, Capkin E, Kayis S (2008) Development of multiplex PCR assay for simultaneous detection of five bacterial fish pathogens. Vet Microbiol 131:332-338

Avendaño-Herrera R (2008) Simultaneous evaluation of four PCR primer sets for the diagnosis of Streptococcus phocae infection. Dis Aquat Org 82:217-222

> Avendaño-Herrera R, Magariños B, Toranzo AE, Beaz R, Romalde JL (2004) Species-specific polymerase chain reaction primer sets for the diagnosis of Tenacibaculum maritimum infection. Dis Aquat Org 62:75-83

Beaz-Hidalgo R, Magi GE, Balboa S, Barja JL, Romalde JL (2008) Development of a PCR protocol for the detection of Aeromonas salmonicida in fish by amplification of the fstA (ferric siderophore receptor) gene. Vet Microbiol 128:386-394

Bravo S (2000) Occurrence of atypical furunculosis in Chile. Bull Eur Assoc Fish Pathol 20:209-211

del Cerro A, Marquez I, Guijarro JA (2002) Simultaneous detection of Aeromonas salmonicida, Flavobacterium psychrophilum, and Yersinia ruckeri, three major fish pathogens, by multiplex PCR. Appl Environ Microbiol 68:5177-5180

Fryer JL, Hedrick R (2003) Piscirickettsia salmonis: a Gramnegative intracellular bacterial pathogen of fish. J Fish Dis 26:251-262

Godoy MG, Aedo A, Kibenge MJ, Groman DB and others (2008) First detection, isolation and molecular characterization of infectious salmon anaemia virus associated with clinical disease in farmed Atlantic salmon (Salmo salar) in Chile. BMC Vet Res 4:28

Godoy M, Gherardelli V, Heisinger A, Fernandez J and others (2010) First description of atypical furunculosis in freshwater Atlantic salmon, Salmo salar L., in Chile. J Fish Dis 33:441-449

> Gonzalez SF, Osorio CR, Santos Y (2003) Development of a PCR-based method for the detection of Listonella anguillarum in fish tissues and blood samples. Dis Aquat Org 55:109-115

> Gustafson CE, Thomas CJ, Trust TJ (1992) Detection of Aeromonas salmonicida from fish by using polymerase chain reaction amplification of the virulence surface array protein gene. Appl Environ Microbiol 58: 3816-3825

Hassan AA, Vossen A, Lämmler C, Siebert U, FernándezGarayzabal JF (2008) PCR amplification of speciesspecific sequences of 16S rRNA and 16S-23S rDNA intergenic spacer region for identification of Streptococcus phocae. Microbiol Res 163:132-135

Hirono I, Masuda T, Auki T (1996) Cloning and detection of the hemolysin gene of Vibrio anguillarum. Microb Pathog 21:173-182

Kulkarni A, Caipang CMA, Brinchmann MF, Kiron V (2009) Simultaneous detection of pathogens causing francisellosis, furunculosis and vibriosis in Atlantic cod by multiplex

Editorial responsibility: Catherine Collins,

Aberdeen, UK polymerase chain reaction. Aquacult Res 41:1533-1538

Lannan CN, Fryer JL (1991) Recommended methods for inspection of fish for the salmonid rickettsia. Bull Eur Assoc Fish Pathol 11:135-136

MacFaddin (1980) Biochemical tests for identification of medical bacteria, 2nd edn. Waverly Press, Baltimore, MD

Marshall S, Heath S, Henriquez V, Orrego C (1998) Minimally invasive detection of Piscirickettsia salmonis in cultivated salmonids via the PCR. Appl Environ Microbiol 64:3066-3069

Mata AI, Gibello A, Casamayor A, Blanco MM, Domínguez L, Fernández-Garayzábal JF (2004) Multiplex PCR assay for detection of bacterial pathogens associated with warm-water streptococcosis in fish. Appl Environ Microbiol 70:3183-3187

Mauel MJ, Giovannoni SJ, Fryer JL (1996) Development of polymerase chain reaction assays for detection, identification, and differentiation of Piscirickettsia salmonis. Dis Aquat Org 26:189-195

> Mauel MJ, Giovannoni SJ, Fryer JL (1999) Phylogenetic analysis of Piscirickettsia salmonis by $16 \mathrm{~S}$, internal transcribed spacer (ITS) and 23S ribosomal DNA sequencing. Dis Aquat Org 35:115-123

Mauel MJ, Ware C, Smith PA (2008) Culture of Piscirickettsia salmonis on enriched blood agar. J Vet Diagn Invest 20:213-214

Mikalsen J, Olsen AB, Tengs T, Colquhoun DJ (2007) Francisella philomiragia subsp. noatunensis subsp. nov. isolated from farmed Atlantic cod (Gadus morhua L.). Int J Syst Evol Microbiol 57:1960-1965

Miyata M, Inglis V, Aoki T (1995) Rapid identification of Aeromonas salmonicida subspecies salmonicida by the polymerase chain reaction. Aquaculture 141:181-185

Nilsson WB, Gudkovs N, Strom MS (2006) Atypical strains of Aeromonas salmonida contain multiple copies of insertion element ISAsa4, useful as a genetic marker and a target for PCR assay. Dis Aquat Org 70:209-217

> Onuk EE, Ciftci A, Findik A, Durmaz Y (2010) Development and evaluation of a multiplex PCR assay for simultaneous detection of Flavobacterium psychrophilum, Yersinia ruckeri and Aeromonas salmonicida subsp. salmonicida in culture fisheries. J Vet Sci 11:235-241

Parada G (2010) Tendencias de la acuicultura mundial y las necesidades de innovación de acuicultura chilena. Informe para el Consejo Nacional de Innovación para la Competitividad, Santiago. http://biblioteca.cnic.cl/media/ users/3/181868/files/18813/G_Parada_ACUI_final.pdf

> Romalde JL, Ravelo C, Valdés I, Magariños B and others (2008) Streptococcus phocae, an emerging pathogen for salmonid culture. Vet Microbiol 130:198-207

> Silva-Rubio A, Avendaño-Herrera R, Jaureguiberry B, Toranzo AE, Magariños B (2008) First description of serotype $\mathrm{O} 3$ in Vibrio anguillarum strains isolated from salmonids in Chile. J Fish Dis 31:235-239

Thompson CC, Vicente AC, Souza RC, Vasconcelos AT and others (2009) Genomic taxonomy of Vibrios. BMC Evol Biol 9:258

Submitted: January 7, 2011; Accepted: July 8, 2011

Proofs received from author(s): November 4, 2011 